\title{
ERRATUM
}

\author{
A. Brachmann · J. König · C. Julius · M. Feldbrügge
}

\section{A reverse genetic approach for generating gene replacement mutants in Ustilago maydis}

Published online: 29 September 2004

(C) Springer-Verlag 2004

\section{Mol Genet Genomics (2004) DOI 10.1007/s00438-004-1047-z}

The plasmid backbone of plasmid pMF1 in Fig.1B was inadvertently depicted the wrong way round. The corrected version is shown below.

Fig. 1 B Schematic representation of the corresponding plasmid system. The optional $g f p$ reporter gene cassette is depicted on the left. $\mathrm{T}_{\text {nos }}$ indicates the

transcriptional terminator of the nopaline synthase gene from Agrobacterium tumefaciens (Bevan et al. 1983). In the center, mandatory resistance cassettes conferring resistance to carboxin $\left(\mathrm{Cbx}^{\mathrm{R}}\right)$, hygromycin $\left(\mathrm{Hyg}^{\mathrm{R}}\right)$, nourseothricin $\left(\mathrm{Nat}^{\mathrm{R}}\right)$ or phleomycin $\left(\mathrm{Phleo}^{\mathrm{R}}\right)$ are shown. The optional promoter cassettes derived from the arabinase gene $\left(\mathrm{P}_{\operatorname{crg} 1}\right)$, the nitrate reductase gene $\left(\mathbf{P}_{\text {narl } 1}\right)$ and the translation elongation factor gene $\left(\mathrm{P}_{\text {ottef }}\right)$ are indicated on the right. The linker sequence between the two $S f i$ I sites and the plasmid structure is depicted (lacZ', $\alpha$ fragment of $\beta$-galactosidase; $\mathrm{Ap}^{\mathrm{R}}$, Ampicillin resistance; oriC, origin of replication) at the bottom
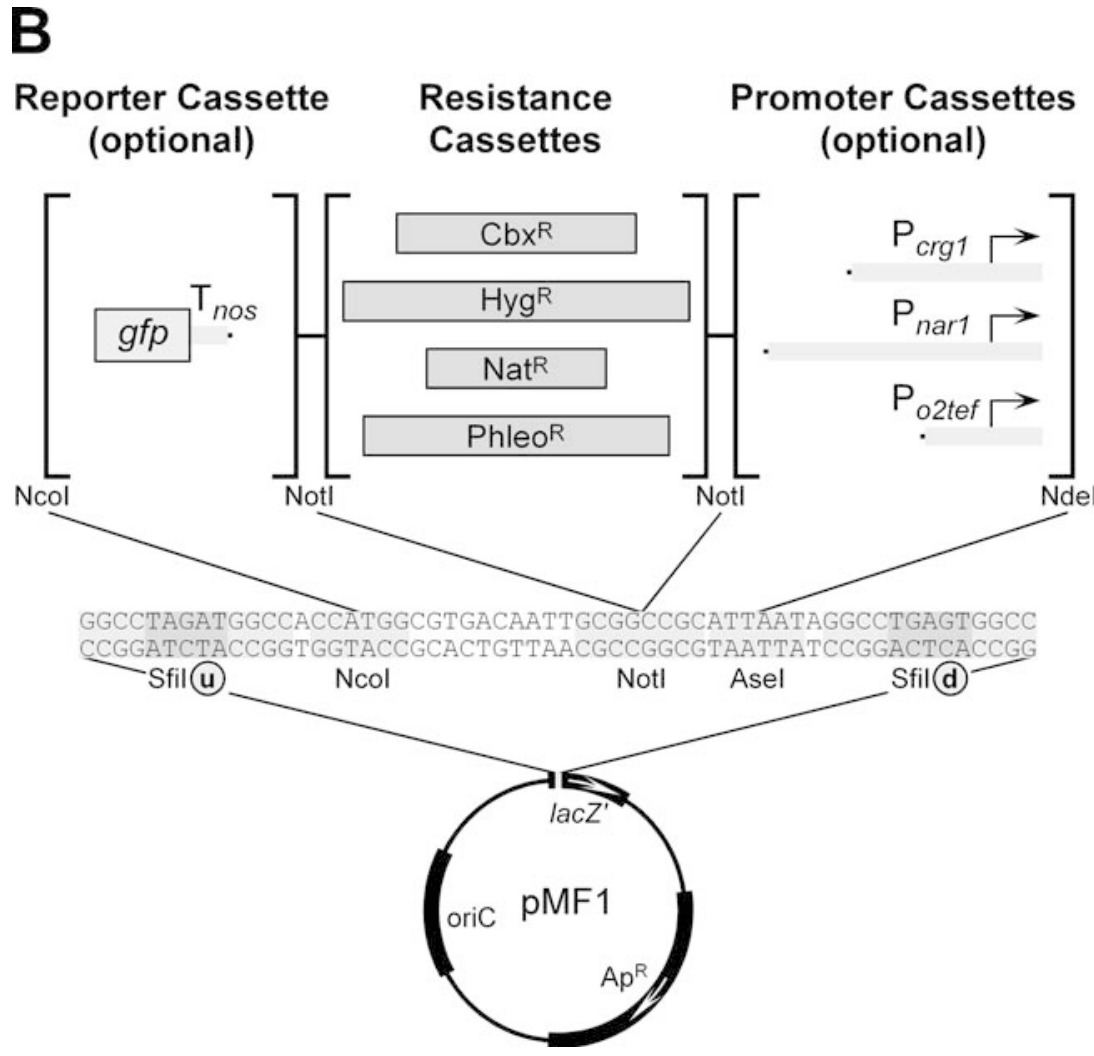

The online version of the original article can be found at http:// dx.doi.org/10.1007/s00438-004-1047-z

A. Brachmann · J. König · C. Julius · M. Feldbrügge $(\bowtie)$

Department of Organismic Interactions,

Max Planck Institute for Terrestrial Microbiology,

Karl-von-Frisch-Strasse, 35043 Marburg, Germany
E-mail: feldbrue@staff.uni-marburg.de

Tel.: + 49-6421-178602

Fax: + 49-6421-178609

Present Address: M. Feldbrügge

National Institute for Diabetes and Digestive and Kidney Diseases, NIH, 8 Center Drive, Bethesda, MD 20892-0830, USA 